\section{JURNAL ABDIMAS

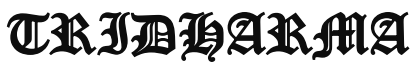

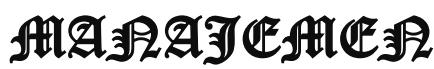

P-ISSN 2615-6849, E-ISSN 2716-070X

Jurnal ABDIMAS Vol. 2,No.3, Agustus 2021,Hal(40-45)

@Prodi Manajemen Fakultas Ekonomi Universitas Pamulang

Email: abdimasjurnal.unpam@ gmail.com Telp: (021) 741-2566

\title{
BAGAIMANA MENINGKATKAN MOTIVASI BELAJAR PADA DIRI PESERTA DIDIK DI ERA PANDEMI COVID-19 PADA YPMS DARUSSALAM KEDAUNG PAMULANG
}

\author{
Agrasadya, Muger Apriansyah, Putri Nilam Kencana, \\ Ading Sunarto, Laila Irawati \\ Dosen Fakultas Ekonomi Bisnis \\ Universitas Pamulang \\ Email dosen01866@unpam.ac.id, \\ dosen01019@unpam.ac.id, dosen01877@unpam.ac.id \\ , dosen02153@unpam.ac.id dosen02205@unpam.ac.id
}

\begin{abstract}
ABSTRAK
Kegiatan pegabdian kepada masyarakat ini bertujuan untuk mensosialisasikan bagaimana meningkatkan motivasi belajar pada diri peserta didik di era pandemi covid19 pada YPMS Darussalam agar menjadi siswa/i yang kreatif dalam menghadapi tantangan di masa pandemic covid-19.

Metode yang digunakan dalam kegiatan Pengabdian Kepada Masyarakat (PKM) ini adalah memberikan sosialisasi serta role play dalam konteks mensosialisasikan bagaimana cara meningkatkan motivasi belajar pada diri peserta didik agar menjadi siswa/i yang kreatif dalam menghadapi pembelajaran di era pandemi covid-19. Adapun tahapan-tahapan yang dilakukan dalam kegiatan ini yaitu: Tahapan Persiapan Mengunjungi YPMS Darussalam Kedaung Pamulang untuk mengajukan proposal Pengabdian Kepada Masyarakat (PKM), Pembagian kerja (jobdesk) anggota kelompok PKM, Penyusunan bahan/materi yang akan dibawakan saat kegiatan PKM berlangsung, Tahapan Pelatihan, Membawakan materi pelatihan (training) tentang bagaimana cara meningkatkan motivasi belajar pada diri peserta didik, Role Play, bagaimana mekanismen pembelajaran yang tepat agar menjadi siswa/i yang kreatif dalam menghadapi pandemi covid-19, Ice Breaking (games), agar peserta pelatihan (siswa/i YPMS Darussalam) tidak mengantuk dan tidak bosan dalam mendengarkan paparan materi.

Hasil pengabdian masyarakat yaitu kami mengunjungi YPMS Darussalam dan mengusulkan proposal yang telah kami buat agar kegiatan PKM dapat direalisasikan. Atas berbagai pertimbangan, akhirnya pimpinan YPMS Darussalam Kedaung Pamulang memutuskan untuk memberikan izin kepada kami, Dosen Program Studi Sarjana Manajemen Universitas Pamulang, untuk dapat mengadakan sosialisasi dan pelatihan kepada peserta didik di YPMS Darussalam Kedaung Pamulang. Judul ini kami anggap penting karena dalam menghadapi era pandemi covid-19 dibutuhkan peningkatan motivasi belajar siswa/i yang kreatif dan kompeten di bidangnya sehingga mampu melaksanakan tugas dan kewajibannya dengan baik dan maksimal. Dengan adanya sosialisasi dan pelatihan ini diharapkan dapat membawa dampak yang positif kepada YPMS Darussalam pada umumnya dan para peserta didik pada khususnya agar semakin termotivasi dan mengembangkan motivasi belajarnya.
\end{abstract}

Kata Kunci: Motivasi, Pandemi, Covid-19 


\section{JURNAL ABDIMAS

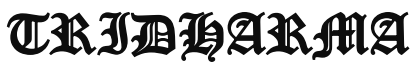

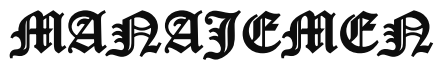

P-ISSN 2615-6849, E-ISSN 2716-070X

Jurnal ABDIMAS Vol. 2,No.3, Agustus 2021,Hal(40-45)

@Prodi Manajemen Fakultas Ekonomi Universitas Pamulang

Email: abdimasjurnal.unpam@ gmail.com Telp: (021) 741-2566

\section{ABSTRAC}

This community service activity aims to socialize how to increase learning motivation in students in the Covid-19 pandemic era at YPMS Darussalam so that they become creative students in facing the challenges of the Covid-19 pandemic.

The method used in this Community Service (PKM) activity is to provide socialization and role play in the context of socializing how to increase learning motivation in students so that they become creative students in facing learning in the Covid-19 pandemic era. The stages carried out in this activity are: Preparation Stages for Visiting YPMS Darussalam Kedaung Pamulang to submit proposals for Community Service (PKM), Division of work (jobdesk) for PKM group members, Preparation of materials / materials that will be delivered during PKM activities, Stages Training, Bringing training materials (training) on how to increase learning motivation in students, Role Play, how to learn the right learning mechanisms to become creative students in the face of the Covid-19 pandemic, Ice Breaking (games), so that training participants (YPMS Darussalam students) are not sleepy and are not bored in listening to the material.

The result of community service was that we visited YPMS Darussalam and proposed a proposal that we had made so that PKM activities could be realized. For various considerations, finally the leadership of YPMS Darussalam Kedaung Pamulang decided to give permission to us, the lecturers of the Pamulang University Management Undergraduate Study Program, to be able to hold outreach and training to students at YPMS Darussalam Kedaung Pamulang. We consider this title important because in the face of the Covid-19 pandemic era, it is necessary to increase the learning motivation of students who are creative and competent in their fields so that they are able to carry out their duties and obligations properly and optimally. With this socialization and training, it is hoped that it can have a positive impact on YPMS Darussalam in general and students in particular to be more motivated and develop their learning motivation.

\section{Keyword : Motivation, Pandemic, Covid-19}

\section{PENDAHULUAN}

Pendidikan adalah suatu bentuk investasi jangka panjang yang penting bagi seorang manusia. Pendidikan yang berhasil akan menciptakan manusia yang pantas dan berkelayakan di masyarakat serta tidak menyusahkan orang lain. Masyarakat dari yang paling terbelakang sampai yang paling maju mengakui bahwa pendidikan atau guru merupakan satu diantara sekian banyak unsur pembentuk utama calon anggota utama masyarakat. Pendidkan yang berhasil akan menciptakan manusia yang pantas dan berkelayakan di masyarakat sehingga menjadi penting pendidikan untuk mencetak manusia yang memiliki berkualitas dan berdaya saing.

Seperti diketahui, motivasi belajar pada siswa tidak sama kuatnya, ada siswa yang motivasinya bersifat intrinsik dimana kemauan belajarnya lebih kuat dan tidak tergantung pada faktor di luar dirinya. Sebaliknya dengan siswa yang motivasi belajarnya bersifat ekstrinsik, kemauan untuk belajar sangat tergantung pada kondisi di luar dirinya. Namun demikian, di dalam kenyataan motivasi ekstrinsik inilah yang banyak terjadi, terutama pada anakanak dan remaja dalam proses belajar. Proses pembelajaran akan berhasil manakala siswa mempunyai motivasi dalam belajar. Oleh karena itu, guru perlu menumbuhkan motivasi belajar siswa. Untuk memperoleh hasil belajar yang optimal, guru dituntut kreatif membangkitkan motivasi belajar siswa. Sebelum masuk kepada bagimana upaya seorang 


\section{JURNAL ABDIMAS

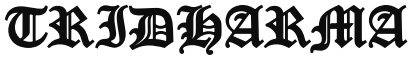

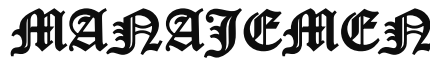

guru dalam memotivasi belajar siswa penulis terlebih dahulu akan membahas tentang apa itu motivasi, yang akan dilanjutkan dengan hal-hal yang perlu dilakukan oleh guru dalam memotivasi belajar siswa, ciri-ciri siswa termotivasi dan fugsi motivasi bagi siswa.

Belajar adalah istilah kunci yang paling vital dalam setiap usaha pendidikan sehingga tanpa belajar sesungguhnya tidak pernah ada pendidikan. Sebagai suatu proses belajar hampir selalu mendapat tempat yang luas dari berbagai disiplin ilmu yang berkaitan dengan upaya pendidikan. Belajar diarahkan untuk tercapainya

pemahaman yang lebuh luas dan mendalam

mengenai proses perubahan manusia itu. Berkembang lebih jauh dari mahluk yang lainnya sehingga boleh jadi karena kemampuan berkembang melalui belajar itulah manusia secara bebas mengeksplorasi, memilih dan menetapkan keputusankeputusan penting untuk kehidupannya. Perubahan dan kemampuan untuk berubah merupakan batasan dan makna yang terkandung dalam belajar. Karena belajarkah maka manusia dapat Belajar adalah sesuatu kegiatan yang tidak dapat dipisahkan dari kehidupan manusia.

Covid-19 telah mengubah banyak hal dalam sekejap. Tidak pernah ada dalam sejarah manusia modern suatu pandemi berlangsung dan menjalar secara cepat seperti Covid-19. Karena itu, setiap peristiwa, respons, dan reaksi seringkali juga bersifat unprecedented. Baik itu pada level individual, komunitas yang paling kecil, sampai dengan negara bangsa. Organisasi dan korporasi juga dipaksa untuk dapat beradaptasi dengan tingkat ketidakpastian yang sangat tinggi. Pandemi telah memaksa kita semua untuk bersiasat secara cepat, tetapi sekaligus akurat. Pemerintah telah menunjukkan kecepatan bersikap yang ditandai dengan realokasi anggaran APBN untuk difokuskan pada penanganan dampak yang ditimbulkan dari pandemi, baik secara sosial maupun ekonomi. Anggaran sebesar kurang lebih Rp405 triliun digeser untuk keperluan tersebut. Perubahan cara dan pola pendidikan yang berfokus pada physical distancing telah memaksa sebagian besar aktivitas di ruang publik seperti sekolah dan perkantoran menjadi berkurang signifikan.

Pembatasan Sosial Berskala

Besar (PSBB) yang diberlakukan oleh pemerintah dan dijalankan sejumlah pemerintah daerah di kotakota besar dan menengah di Indonesia membuat aktivitas pendidikan ikut berubah.

Harus disadari, yang dimaksud dengan kondisi new normal bukanlah kondisi di mana tidak ada lagi virus Covid-19 di tengah-tengah kita. Mengharapkan itu terjadi adalah sesuatu yang mustahil. New normal adalah kondisi di mana setiap orang harus menyesuaikan diri dengan kondisi baru di mana ancaman virus itu tetap nyata dan bisa menghinggapi siapa saja. Yang dibutuhkan adalah kewaspadaan yang makin tinggi, kedisiplinan yang makin kuat, dan dalam konteks tersebut, sekolah harus juga dapat menjadi salah satu garda depan untuk menciptakan kondisi new normal tersebut.

Sekolah sebagai sarana pendidikan juga menjadi sektor yang terdampak, sehingga menyebabkan pembelajaran harus dilakukan jarak jauh (PJJ).

\section{RUMUSAN MASALAH}

Berdasarkan latar belakang masalah di atas, maka dapat dirumuskan permasalahannya yaitu Mengapa diperlukan peningkatan motivasi belajar pada diri peserta didik? Dan Bagaimana cara meningkatkan motivasi belajar pada diri peserta didik di era pandemi covid-19?

\section{TUJUAN PELAKSANAAN}

1. Mensosialisasikan kepada peserta didik pada YPMS Darussalam cara meningkatkan motivasi belajar 


\section{JURNAL ABDIMAS

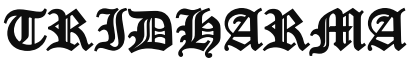

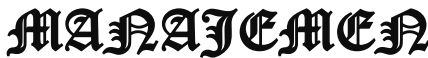

P-ISSN 2615-6849, E-ISSN 2716-070X

Jurnal ABDIMAS Vol. 2,No.3, Agustus 2021,Hal(40-45)

@Prodi Manajemen Fakultas Ekonomi Universitas Pamulang

Email: abdimasjurnal.unpam@ gmail.com Telp: (021) 741-2566 di era pandemic covid-19.

2. Memotivasi peserta didik pada YPMS Darussalam agar menjadi siswa/i yang maju dan kreatif di tengah pandemic covid-19.

\section{TINJAUAN PUSTAKA}

Kata motif sering diartikan sebagai daya dalam diri seseorang untuk melakukan sesuatu. Motif adalah sebab yang menjadi dorongan tindakan seseorang. Motif diartikan sebagai daya yang mendorong seseorang untuk melakukan sesuatu. Motif dapat dikatakan sebagai daya penggerak dari dalam diri subyek untuk melakukan aktivitsaktivitas tertentu demi mecapai suatu tujuan. Bahkan motif dapat diartikan sebagai kondisi intern. (kesiapsiagaan), berawal dari kata motif itu, makaka motivasi dapat diartikan sebagai daya penggerak yang telah menjadi aktif. Motif menjadi aktif pada saat tertentu, terutama bila kebutuhan untuk mencapai tujuan dapat dirasakan/mendesak (sardiman, 2011).

Motivasi dipandang sebagai dorongan mental yang menggerakkan dan mengarahkan prilaku manusia termasuk prilaku belajar. Dalam motivasi terkandung adanya keinginan, harapan, tujuan, sasaran, dan insentif. Keadaan inilah yang mengaktifkan, menggerakkan, menyalurkan, dan mengarahkan sikap dan perilaku individu belajar (Dimyati dan Mudjono, 2010). Motivasi merupakan kekuatan yang mendorong manusia untuk melakukan sesuatu dalam mencapai tujuan. Hal tersebut, terlaksana karena dirangsang dari berbagai macam kebutuhan atau keinginan yang hendak dipenuhi. Komponen utama motivasi, yaitu: a) kebutuhan, b) perilaku/dorongan, dan c)

tujuan. Untuk mewujudkan terjadinya belajar, motivasi mempunyai kedudukan yang Sangat penting artinya bagi peserta didik, diantaranya adalah memperbesar semangat belajar. Ali (2010:14) mengemukakan bahwa belajar adalah "proses perubahan perilaku, akibat interaksi individu dengan lingkungan". Menurut Sardiman (2011:22) "Belajar dalam arti luas, dapat diartikan sebagai kegiatan psiko-fisik menunjukkan perkembangan pribadi seutuhnya". Disini dapat dilihat bahwa belajar merupakan sarana pengembangan pribadi dari individu yang melakukannya. Lebih lanjut Sardiman (2011:22) juga mendefinisikan belajar dalam arti sempit yaitu "Belajar dimaksudkan sebagai usaha penguasaan materi ilmu pengetahuan yang merupakan sebagai kegiatan menuju terbentuknya kepribadian seutuhnya".

Dari pendefinisian tersebut, dapat diartikan bahwa belajar adalah suatu usaha pengembangan diri. Menurut Sahabuddin (2007: 131-134) bahwa prinsip-prinsip belajar meliputi: 1) Pernyataan tujuan yang jelas, 2) Menjelaskan mengenai bagaimana belajar, 3) Perbuatan yang diharapkan dari siswa, 4) Tinjauan menyeluruh tentang materi yang dipelajari, 5) Mengoptimalkan tugas-tugas belajar, 6) Tinjauan berkala, 7) Aktif Belajar, 8) Alasan mempelajari keterampilan dan informasi, 9) aplikasi materi yang telah dipelajari, 10) motivasi intrinsik, ekstrinsik dan insentif, 11) mengajarkan kepada orang lain, 12) menggunakan pelajaran yang terorganisasi baik, 13) menggunakan prinsip lanjutan dan kaitan. Belajar adalah semua upaya manusia atau individu memobilisasikan (menggerakkan, mengerahkan dan mengarahkan semua sumber daya manusia yang dimilikinya (fisik, mental, Intelektual, Emosional dan Sosial) untuk memberikan jawaban (respons) yang tepat terhadap problema yang dihadapinya. Dalam proses balajar haruslah diperhatikan prinsip belajar. Karena proses belajar memang kompleks tetapi dianalisis dan diperinci dalam bentuk prinsip-prinsip atau asas-asas belajar. Hal ini perlu diketahui agar kita memiliki pedoman dalam belajar secara efisien. Prinsipprinsip tersebut antara lain: 1 . 


\section{JURNAL ABDIMAS

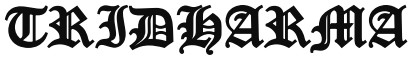

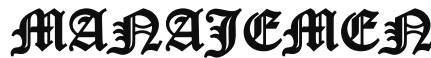

Belajar adalah suatu proses aktif dimana terjadi hubungan saling mempengaruhi secara dinamis antara siswa dengan lingkungan. 2. Belajar senantiasa

harus bertujuan, terarah dan jelas bagi siswa. Tujuan akan menuntunnya dalam belajar untuk

mencapai harapan-harapannya. 3. Belajar paling efektif apabila didasari oleh dorongan motivasi yang murni dan bersumber dari dalam diri sendiri.

definisi mengenai motivasi belajar. Diantaranya yaitu sebagai berikut: Motivasi belajar adalah dorongan internal dan eksternal pada siswa-siswa yang sedang belajar untuk mengadakan perubahan tingkah laku, pada umumnya dengan beberapa indikator atau unsur yang mendukung. (Uno, 2011). Motivasi belajar adalah keseluruhan daya penggerak di dalam diri siswa yang menimbulkan kegiatan belajar, menjamin kelangsungan kegiatan belajar dan memberikan arah pada kegiatan belajar itu demi mencapai suatu tujuan. (Winkel, 2009). Sedangkan Prayitno (Riduwan, 2010) menyatakan bahwa "Motivasi belajar tidak saja merupakan suatu energi yang menggerakkan siswa untuk belajar, tetapi juga sebagai sesuatu yang mengarahkan aktivitas siswa kepada tujuan belajar". Dari penjelasan beberapa ahli tersebut, dapat disimpulkan bahwa motivasi belajar adalah dorongan, baik itu yang bersifat internal maupun eksternal, yang dapat mengarahkan siswa untuk melakukan kegiatan belajar agar dapat mencapai tujuan belajar. Motivasi timbul dan tumbuh berkembang dengan jalan: (1) Datang dari dalam diri individu itu sendiri (intrinsik); dan (2) Datang dari lingkungan (ekstrinsik). (Syamsuddin, 2005).

Ada beberapa prinsip motivasi belajar yang dapat dijadikan acuan antara lain: (Surya, 2003). a. Prinsip kompetisi Yaitu persaingan secara sehat, baik dalam diri pribadi maupun antar pribadi. b. Prinsip pemacu Yaitu dorongan yang diberikan untuk melakukan berbagai tindakan yang diberikan secara teratur, baik melalui bimbingan maupun nasehat-nasehat. c. Prinsip ganjaran dan hukuman Contohnya seperti pemberian pujian kepada siswa. Hal ini dapat menguatkan motivasi dalam diri siswa untuk melakukan tindakan tersebut secara terus menerus. d. Kejelasan dan kedekatan tujuan Semakin jelas dan semakin dekat suatu tujuan, maka akan semakin mendorong seseorang untuk melakukan tindakan tersebut. e. Pemahaman hasil Hasil atau prestasi yang dicapai seseorang merupakan umpan balik dari upaya yang telah dilakukannya, dan hal tersebut dapat memberikan motivasi untuk melakukan tindakan selanjutnya.

f. Pengembangan minat Minat dapat diartikan sebagai rasa sengan atau tidak senang dalam menghadapi suatu objek. Motivasi akan cenderung meningkat apabila memiliki minat

yang besar dalam belajar. g. Lingkungan yang kondusif Baik lingkungan fisik, sosial maupun psikologis yang kondusif dapat menumbuhkan dan mengembangkan motivasi untuk bekerja dengan baik dan produktif. h. Keteladanan Perilaku pengajar (guru) secara langsung atau tidak langsung, mempunyai pengaruh terhadap perilaku siswa yang baik, yang sifatnya positif maupun negatif.

\section{HASIL DAN PEMBAHASAN}

Kami mengunjungi YPMS Darussalam dan mengusulkan proposal yang telah kami buat agar kegiatan PKM dapat direalisasikan. Atas berbagai pertimbangan, akhirnya pimpinan YPMS Darussalam Kedaung Pamulang memutuskan untuk memberikan izin kepada kami, Dosen Program Studi Sarjana Manajemen Universitas Pamulang, untuk dapat mengadakan sosialisasi dan pelatihan kepada peserta didik di YPMS Darussalam Kedaung Pamulang. Judul ini kami anggap penting karena dalam 


\section{JURNAL ABDIMAS

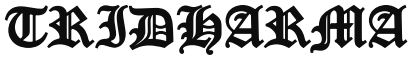

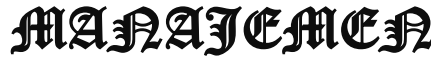

P-ISSN 2615-6849, E-ISSN 2716-070X

Jurnal ABDIMAS Vol. 2,No.3, Agustus 2021,Hal(40-45)

@Prodi Manajemen Fakultas Ekonomi Universitas Pamulang

Email: abdimasjurnal.unpam@ gmail.com Telp: (021) 741-2566 menghadapi era pandemic covid-19 dibutuhkan peningkatan motivasi belajar siswa/i yang kreatif dan kompeten di bidangnya sehingga mampu melaksanakan tugas dan kewajibannya dengan baik dan maksimal. Dengan adanya sosialisasi dan pelatihan ini diharapkan dapat membawa dampak yang positif kepada YPMS Darussalam pada umumnya dan para peserta didik pada khususnya agar semakin termotivasi dan mengembangkan motivasi belajarnya.

\section{KESIMPULAN DAN SARAN \\ Kesimpulan}

Kegiatan Pengabdian Kepada Masyarakat (PKM) yang telah kami lakukan ini pada dasarnya adalah berkat kerjasama berbagai pihak terkait sehingga kegiatan dapat berjalan dengan baik dan terukur, serta materi yang kami sampaikan dapat bermanfaat bagi peserta didik pada YPMS Darussalam. Dengan adanya kegiatan Pengabdian Kepada Masyarakat (PKM) ini, diharapkan peserta dapat mengaplikasikan ilmu yang telah mereka peroleh dalam kehidupan sehari-hari. Dan pada akhirnya, ilmu tersebut dapat dirasakan manfaatnya oleh peserta sendiri dan lingkungan di sekitarnya, khususnya lingkungan YPMS Darussalam Kedaung Pamulang.

\section{Saran}

Saran kami terhadap Yayasan, dalam hal ini YPMS Darussalam Kedaung Pamulang Tangerang Selatan, adalah hendaknya Yayasan lebih memperhatikan cara belajar siswa/i agar mereka lebih termotivasi dalam belajar, memfasilitasi pembelajaran dengan pelatihan (training) secara berkala tentang bagaimana meningkagtkan motivasi belajar peserta didik dalam menghadapi pembelajaran di era pandemi covid-19 dan agar menjadi siswa/i yang kreatif untuk menghadapi kondisi dan situasi pembelajaran di era pandemi seperti sekarang ini sehingga peserta didik semakin kompeten dalam melaksanakan tugas sesuai dengan tanggung jawabnya masing-masing dan memberikan dampak positif bagi kemajuan YPMS Darussalam di masa yang akan datang.

\section{DAFTAR PUSTAKA}

Abin Syamsuddin Makmun. (2003).

Psikologi Pendidikan. Bandung:

Remaja Rosdakarya offset.

Ali, 2010. Konsep dukungan keluarga. Jakarta: salemba medika

A.M. Sardiman. 2011. Interaksi dan Motivasi Belajar Mengajar. PT Rajagrafindo: Jakarta

Andriani, D., \& Sojanah, J. (2017). UPAYA MENINGKATKAN KOMPETENSI SISWA MELALUI MOTIVASI BELAJAR. Jurnal Pendidikan Manajemen Perkantoran (JPManper), 2(1), 1019.

Aritonang, K. T. (2008). Minat dan motivasi dalam meningkatkan hasil belajar siswa. Jurnal pendidikan penabur, 7(10), 11-21.

Ading, S. (2020). PENGARUH GAYA KEPEMIMPINAN, MOTIVASI, SERTA DISIPLIN KERJA TERHADAP KINERJA KARYAWAN (Study di PT Mitsui Leasing Capital Indonesia Abdul Muis-Jakarta Pusat). KREATIF: Jurnal Ilmiah Prodi Manajemen Universitas Pamulang, 8(1), 18-38.

Agrasadya, A., Sunarto, A., Kencana, P. N., Munadjat, B., \& Sicillia, M. (2020). MEMBANGUN KARAKTERISTIK PESERTA DIDIK DI ERA REVOLUSI INDUSTRI $4.0 \quad$ YANG DILANDASI DENGAN IMTAQ. JURNAL LOKABMAS KREATIF, 1(2), 56-61.

Dimyati dan Mujiono. 2010. Belajar dan Pembelajaran. Jakarta: PT. Rineka Cipta 


\section{JURNAL ABDIMAS

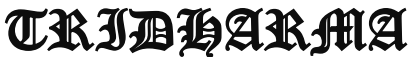

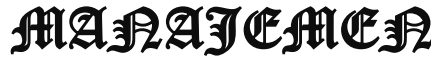

P-ISSN 2615-6849, E-ISSN 2716-070X

Jurnal ABDIMAS Vol. 2,No.3, Agustus 2021,Hal(40-45)

@Prodi Manajemen Fakultas Ekonomi Universitas Pamulang

Email: abdimasjurnal.unpam@gmail.com Telp: (021) 741-2566
Dumilah, R., Sunarto, A., Ahyani, A., Solihin, D., \& Maulida, H. (2020). Pelatihan Pemanfaatan Media Sosial Untuk Promosi Usaha Atau Bisnis Bagi Siswa. DEDIKASI PKM, 1(1), 26-33.

Hendra Surya. 2011. Strategi Jitu Mencapai Kesuksesan Belajar. Jakarta: Kompas Media

Lismiatun, L., Fadillah, F., \& Kencana, P. N. (2020). PROGRAM MENTORING DAN MOTIVATING DALAM MELATIH KEMANDIRIAN SISWA/I SEKOLAH MENENGAH KEJURUAN DARUSSALAM, CIPUTAT, TANGERANG SELATAN. Jurnal ABDIMAS Tri Dharma Manajemen, 1(3), 1-7.

Pasaribu, V. L. D., Agrasadya, A., Shabrina, N., \& Krisnaldy, K. (2020). Menjadi Enterpreneur Muda Yang Memiliki Jiwa Leadership Untuk Menghadapi Masa Depan. Abdi Laksana: Jurnal Pengabdian Kepada Masyarakat, 1(1).

Sunarto, A., Sartika, D., Cay, S., Sumiyati, R. Y., \& Nurhidayat, M. A. (2020). MENINGKATKAN MOTIVASI BELAJAR PESERTA DIDIK DIRUMAH MASINGMASING SELAMA MASA PANDEMIC COVID-19 PADA YPMS DARUSSALAM KEDAUNG PAMULANG. DEDIKASI PKM, 2(1), 14-20.

Sartika, D., Cay, S., Sunarto, A., Nurhidayat, M. A., \& Sumiaty, R. Y. (2020). Meningkatkan Disiplin dan Tanggung Jawab Peserta Didik di Era Revolusi Industri 4.0. DEDIKASI PKM, 1(2), 44-49.

Sahabudin. (2007). Mengajar dan Belajar, Bandung: Alfabeta

Suprihatin, S. (2015). Upaya guru dalam meningkatkan motivasi belajar siswa. Jurnal Pendidikan Ekonomi UM Metro, 3(1), 73-82.

Uno, H.(2011). Teori Motivasi dan Pengukurannya. Jakarta: PT Bumi AksaraBandung PT Remaja Rosdaka Karya
Winkel, W.S. (2009). Psikologi Pengajaran. Jakarta : Gramedia.

\section{DOKUMENTASI KEGIATAN}
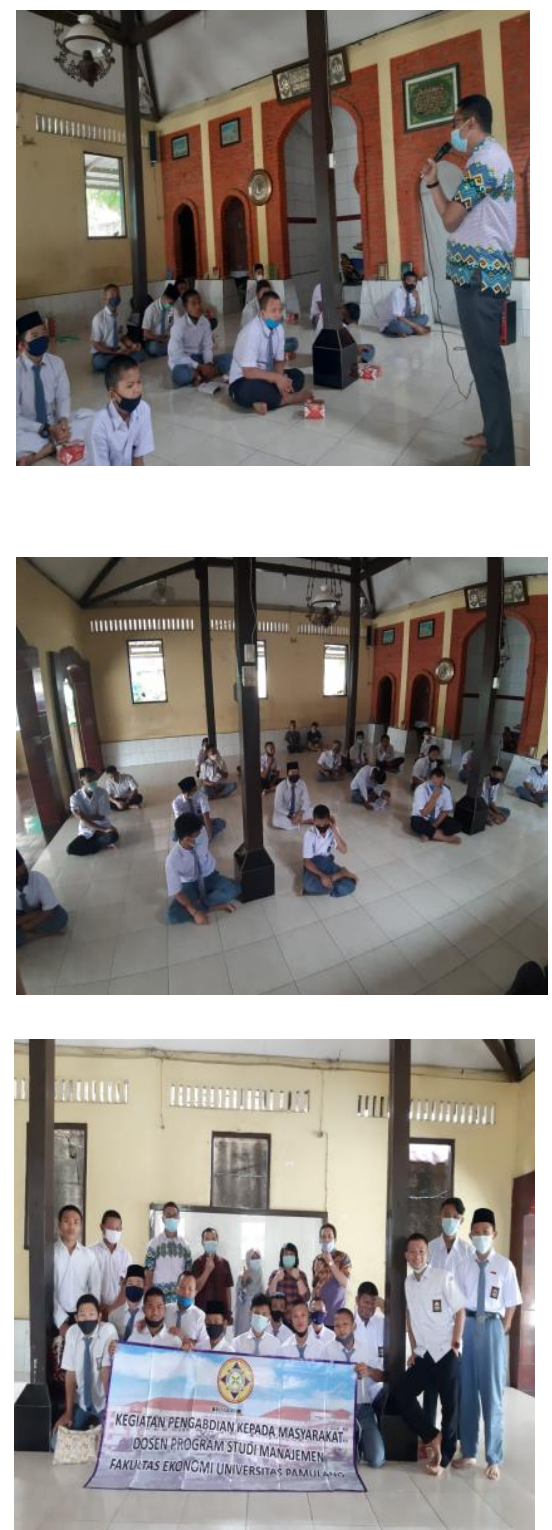